International Journal of Current Microbiology and Applied Sciences

ISSN: 2319-7706 Volume 6 Number 8 (2017) pp. 718-724

Journal homepage: http://www.ijcmas.com

Original Research Article

https://doi.org/10.20546/ijcmas.2017.608.091

\title{
Water and Fertilizer Use Management for Improving Smallholder Farmers' Tomato Production in the Dry Savanna Agro Ecology of West Africa
}

\section{Jean Mianikpo Sogbedji ${ }^{1 *}$, Kodjovi Sotomè Detchinli ${ }^{1}$, Kossivi Koukoude ${ }^{2}$, Robert Baname Gbengbernaba ${ }^{3}$ and Jean Tadanlenga Yatombo ${ }^{3}$}

\author{
${ }^{1}$ Département des Sciences du sol, Ecole Supérieure d'Agronomie, Université de Lomé. \\ 01BP 1515 Lomé 01, Togo \\ ${ }^{2}$ International Fertilizer Development Center, Lomé, Togo. 4483 Lomé, Togo \\ ${ }^{3}$ RAFIA (Recherche Appui et Formation aux Initiatives d'Auto-développement). \\ BP 43 Dapaong, Togo \\ *Corresponding author
}

\begin{tabular}{|c|c|}
\hline & A B S T R A C T \\
\hline Keywords & \multirow{4}{*}{ 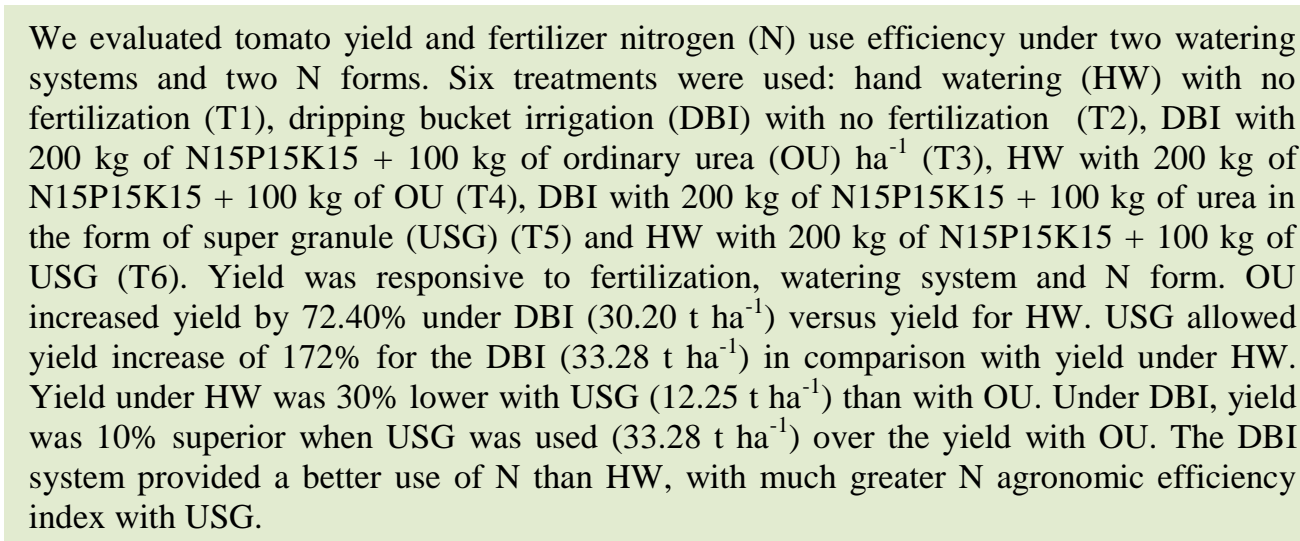 } \\
\hline $\begin{array}{l}\text { Water use } \\
\text { efficiency, } \\
\text { Vegetable crops, } \\
\text { Fertilization, } \\
\text { Nitrogen. }\end{array}$ & \\
\hline Article Info & \\
\hline $\begin{array}{l}\text { Accepted: } \\
\text { 04 June } 2017 \\
\text { Available Online: } \\
\text { 10 August } 2017\end{array}$ & \\
\hline
\end{tabular}

\section{Introduction}

Improving smallholder farmers' livelihoods demands that water resources available to them and small amounts of other inputs particularly fertilizer they can afford to buy be efficiently used. Vegetable cropping plays a key role in sub-Saharan Africa (SSA) because it represents an asset to backing-up farmers' incomes from other crops (de la Peña and Hughes 2007) and to enhancing food security and children education (IFDC 2014). Vegetables are the best resource for overcoming micronutrient deficiencies and provide smallholder farmers with much higher income and more jobs per hectare than staple crops (AVRDC, 2006). In resourcepoor rural communities especially in SSA, vegetable production is undertaken by farmers through water source constraints (Abramson et al., 2011) and traditional practices based on hand watering. Such practices have the drawback of increasing working time due to frequent soil crusting, important amount inputs use because they are regularly washed away by the watering system, stressing the 
plant and damaging flowers/fruits. This results in low yields with minimal benefit (FAO, 2006). Alternative practices are therefore needed to reverse the downward trend in vegetable production in the region for the sake of food security and poverty alleviation.

The maintenance of nutrients and water at optimum levels within the rhizosphere of plants is a primary factor for achieving higher yields, and increased fertilizer and water use efficiencies. However, the world now faces very serious global warming problem and therefore, concern of newer and more efficient irrigation methods is in demand. At the same time, adequate fertilization both in time and through application methods to maintain optimum nutrient supply for optimum growth and development of the crop are also equally important towards the higher productivity. Low-cost drip irrigation (LCDI) has emerged as a means to address these challenges through increased water use efficiency, labour savings, and higher economic returns (Ngigi et al., 2005; Polak et al., 2003). A recent study (Woltering et al., 2011) quantified the time savings and economic gains associated with drip irrigation for smallholders. Fertilizers should be applied in a form that becomes available in synchrony with crop demand for maximum utilization of nutrients from fertilizers to enhance productivity (Boyhan et al., 2001). Recent research efforts in West Africa (Detchinli and Sogbedji 2015; IFDC 2013) demonstrated that deep placement of fertilizer $\mathrm{N}$ in the form of urea super granule (USG) proved superiority over the ordinary urea form of $\mathrm{N}$ in terms of crop yield and associated economic profitability and nutrient use efficiency for maize cropping. Although LCDI has emerged as an alternative to more costly conventional drip systems, studies comparing the performance of LCDI with either conventional drip irrigation systems or the most popular careful hand watering used in the region are scarce. Furthermore, no research efforts have been performed using the USG-based fertilizer deep placement technology in vegetable cropping in the region.

The objective of this study was to quantitatively assess the effect of watering and fertilization practices on tomato yield and $\mathrm{N}$ use efficiency under tomato cropping. The aim was to identify approaches that improve smallholder farmers' vegetable based production.

\section{Materials and Methods}

\section{Study area}

The study was conducted in the Sudan Savanna agro ecological zone of northern Togo $\left(10-11^{\circ} \mathrm{N}, 0-1^{\circ} \mathrm{E}\right)$. The dominant soil type was a rhodic ferruginous sol that is sandy-clayed at the top horizon and clayedsandy or sandy-clayed at the horizon of alteration (DRPDATS, 2013). Organic matter widely varied from 0.8 to $1.6 \%$, the $\mathrm{pH}$ ranged from 5.8 to 6 , and total $\mathrm{N}$ and $\mathrm{P}$ and sum of exchangeable bases were $0.08 \%$, $0.095 \mathrm{ppm}$ and 7 to $20 \mathrm{meq}$, respectively.

The rainfall regime is monomial with annual rainfall typically ranging from 1000 to 13000 $\mathrm{mm}$ and occurring generally from May to October. The off-season covers the period from November to April during which vegetable cropping is undertaken. Yearly average minimum and maximum temperature values are 22 and $35^{\circ} \mathrm{C}$ with highest values in March and November $\left(33\right.$ and $38^{\circ} \mathrm{C}$, respectively) and lowest values in January and August $\left(15^{\circ} \mathrm{C}\right.$ and $17^{\circ} \mathrm{C}$, respectively) (DRPDATS 2013). The family-based fields used in the study were under continuous unfertilized maize or sorghum crops. 
Soil, crop and watering management

A 2-off season period (2013-2014) experiment was established with two watering regimes crossed with three fertilization schemes leading to six treatments in three replicates each. The experiment was settled in thirty farmer-family fields selected in the study area (savanna region of Togo). The applied six treatment were as follow: (i) farmer's based hand watering (HW) with no fertilizer application (T1), (ii) dripping bucket irrigation (DBI) system with no fertilizer application (T2), (iii) DBI system with application of $200 \mathrm{~kg}$ of N15P15K15 + 100 $\mathrm{kg}$ of prilled, ordinary urea $(46 \% \mathrm{~N})$ corresponding to $\mathrm{N}_{76} \mathrm{P}_{30} \mathrm{~K}_{30} \mathrm{ha}^{-1}$ (T3), (iv) HW with application of $200 \mathrm{~kg}$ of $\mathrm{N} 15 \mathrm{P} 15 \mathrm{~K} 15+100 \mathrm{~kg}$ of prilled, ordinary urea $(46 \% \mathrm{~N})$ corresponding to $\mathrm{N}_{76} \mathrm{P}_{30} \mathrm{~K}_{30} \mathrm{ha}^{-1}$ (T4), (v) DBI system with application of 200 $\mathrm{kg}$ of $\mathrm{N} 15 \mathrm{P} 15 \mathrm{~K} 15+100 \mathrm{~kg}$ of urea $(46 \% \mathrm{~N})$ in the form of super granule (USG) corresponding to $\mathrm{N}_{76} \mathrm{P}_{30} \mathrm{~K}_{30} \mathrm{ha}^{-1}$ (T5) and (vi) HW with application of $200 \mathrm{~kg}$ of $\mathrm{N} 15 \mathrm{P} 15 \mathrm{~K} 15+100 \mathrm{~kg}$ of urea $(46 \% \mathrm{~N})$ in the form of super granule (USG) corresponding to $\mathrm{N}_{76} \mathrm{P}_{30} \mathrm{~K}_{30}$ ha ${ }^{-1}$ (T6). The $\mathrm{N}_{76} \mathrm{P}_{30} \mathrm{~K}_{30}$ ha $^{-1}$ is a recommendation by the national agricultural extension services in Togo and the two forms of urea- $\mathrm{N}$ fertilizer used in the experiment are presented in figure 1. The DBI system is a small scale design (for up to $500 \mathrm{~m}^{2}$ ) with buckets of 200 litres (filled with water by hand) releasing water to crops through a dripping system by simple gravity. The bucket is kept a $1.2 \mathrm{~m}$ above the soil surface and is equipped with two dripping pipes that feed each two $15 \mathrm{~m}$ - long rows of tomato plants on a point-placed water basis for each plant. The DBI system design and its in-field setting are presented in figure 2 .

The site in each farmer family field was manually ploughed and 18 plant beds (15 m x $1.80 \mathrm{~m}$ ) for the six treatments with three replicates each were laid out in a completely randomized design. Fertilizer $\mathrm{N}_{76} \mathrm{P}_{30} \mathrm{~K}_{30}$ ha $^{-1}$ rate was applied three weeks after tomato planting as recommended by the national agricultural research and extension services in the region. In each off-season of each of the two years, all fertilizers were manually pointplaced at approximately $8 \mathrm{~cm}$ depth. Tomato (Tropimech, the most used variety) was planted in November at a density of 74,000 plants $\mathrm{ha}^{-1}$, weeded as needed and the harvest ended in March-April.

\section{Data collection and analysis}

Tomato fresh fruit yield was determined under each treatment by harvesting all the plants from each plant bed. The GENSTAT statistical software package was used to run the analysis of variance (ANOVA) on the yield data sets and the Duncan test at 5\% was used to discriminate among mean tomato yields. Mean tomato fruit yield data were used to calculate the $\mathrm{N}$ agronomic efficiency Index using the approach of Fathi (1996) represented by the following equation:

$\mathrm{N}$ agronomic efficiency Index $=(\mathrm{A}-\mathrm{B}) / \mathrm{C}(1)$

Where $A$ is yield of plant that obtains a fertilizer, B is yield of plant that obtains a minimum amount of fertilizer and $\mathrm{C}$ is the consumed fertilizer.

\section{Results and Discussion}

\section{Tomato fresh fruit production}

Tomato yield data are presented in table 1. Mean yield typically ranged from 8 to 34 tha 1 . Across treatments, mean yield were 18.78 and $18.86 \mathrm{t} \mathrm{ha}^{-1}$ for the first and the second seasons, respectively, indicating that there was no seasonal effect on the data. Tomato yield was responsive to fertilization scheme, watering system and their interactions, being 
on average lowest (8.83 and $10.85 \mathrm{t} \mathrm{ha}^{-1}$ ) with no fertilizer and ranging from 12.25 to $33.28 \mathrm{t}$ $\mathrm{ha}^{-1}$ when fertilizer was applied. This indicates that in the region, improvement in tomato production is subject to mineral fertilizer use.

Under no fertilizer treatments, seasonal mean yield for DBI (10.85 $\mathrm{t} \mathrm{ha}^{-1}$ ) was $23 \%$ superior over the HW system (8.83 $\mathrm{t} \mathrm{ha}^{-1}$ ) (Table 1). With the use of ordinary (prilled) urea, mean yield increased by $72.40 \%$ under DBI $(30.20 \mathrm{t}$ $\mathrm{ha}^{-1}$ ) as compared with yield for the HW system $\left(17.52 \mathrm{t} \mathrm{ha}^{-1}\right)$. The use of USG resulted in yield increase of $172 \%$ for the DBI (33.28 $\left.\mathrm{t} \mathrm{ha}^{-1}\right)$ in comparison with yield under the HW system $\left(12.25 \mathrm{t} \mathrm{ha}^{-1}\right)$. These trends of the data set clearly demonstrate the superiority of the DBI system over the HW system in terms of fresh tomato fruit yield. This finding of our study corroborated several other research results. Kaniszewski and Dysko (1988) reported lowest tomato yield with hand watering in comparison with micro-jet and dripping irrigation systems and von Westarp et al., (2004) in their study on cauliflower concluded that low cost drip irrigation and hand watering are both viable options to increase food production in water scarce, small-scale farming in Nepal, with a greater performance of the drip irrigation system.

Seasonal mean tomato yield under HW was $30 \%$ lower when fertilizer $\mathrm{N}$ was applied in the form of USG (12.25 $\mathrm{t} \mathrm{ha}^{-1}$ ) as compared with yield associated with the use of ordinary (prilled) urea $\left(17.52 \mathrm{t} \mathrm{ha}^{-1}\right)$. The data set showed that under DBI, yield was $10 \%$ superior when USG was used (33.28 $\left.\mathrm{t} \mathrm{ha}^{-1}\right)$ over the yield obtained using prilled urea $\left(30.20 \mathrm{tha}^{-1}\right)$. This shows that on the basis of $\mathrm{N}$ fertilizer form, both $\mathrm{N}$ forms (USG and prilled urea) performed well under the DBI system with a greater performance of USG, but USG led to severe yield depression under the HW system indicating that using this form of $\mathrm{N}$ is not advised for the traditional HW practice. Studies comparing the performance of the USG and ordinary forms of $\mathrm{N}$ fertilizer in vegetable cropping are lacking. However, Detchinli and Sogbedji (2015) in a maize crop based experiment in West Africa found that $\mathrm{N}$ fertilizer in the USG form proved superiority over the ordinary urea form under low $(30 \mathrm{~kg}$ $\left.\mathrm{ha}^{-1}\right)$ and high (90 $\left.\mathrm{kg} \mathrm{ha}^{-1}\right) \mathrm{N}$ rates of application. Furthermore, studies by Tarfa and Ahmed (2011) in Nigeria and IFDC (2014) in Ghana under irrigated rice cropping reported higher rice yields with the USG than those with ordinary urea.

\section{Nitrogen agronomic efficiency index}

The $\mathrm{N}$ agronomic efficiency index values are presented in table 1. In contrast to tomato yield, mean $\mathrm{N}$ agronomic efficiency index values experienced seasonal variation across treatments, being $13 \%$ higher in the second season (311) than in the first season (274). With the use of ordinary (prilled) urea, mean index increased by $122 \%$ under DBI (420) as compared with index for the HW system (189). The use of USG resulted in index increase of $558 \%$ for the DBI (487) in comparison with index under the HW system (74). Similar to yield data, the N agronomic efficiency index data show that the DBI system provided a better use of the $\mathrm{N}$ fertilizer than the HW system.

Mean $\mathrm{N}$ agronomic index under $\mathrm{HW}$ was $154 \%$ higher when fertilizer $\mathrm{N}$ was applied in the form of ordinary urea (189) as compared with index using USG (74). The data set showed that under DBI, index was $16 \%$ superior when USG was used (487) over the index obtained using prilled urea (420). This shows that on the basis of $\mathrm{N}$ fertilizer form, both $\mathrm{N}$ forms (USG and prilled urea) performed well under the DBI system with a greater performance when USG was used, but 
USG resulted in very low $\mathrm{N}$ agronomic efficiency index under the HW system. Besides the lowest index value of 74 recorded from the HW system with USG, seasonal mean index values from this study ranged from 189 to 487 which reasonably agreed with tomato $\mathrm{N}$ agronomic efficiency index values of 185 to 275 published by Badr et al., (2012) and 142 to 441 reported by Djidonou et al., (2013).

Table.1 Mean tomato yield and $\mathrm{N}$ fertilizer agronomic efficiency index

\begin{tabular}{|l|c|c|c|c|c|c|}
\hline Treatment & \multicolumn{3}{|c|}{${\text { Yield }\left(\mathbf{t ~ h a}^{-1}\right)}^{\text {) }}$} & \multicolumn{3}{c|}{ N agronomic efficiency index } \\
\hline & Season 1 & Season 2 & Mean & Season 1 & Season 2 & Mean \\
\hline \hline T1 & $9.50 \mathrm{a}^{\text {Il }}$ & $8.16 \mathrm{a}$ & $8.83 \mathrm{a}$ & - & - & - \\
\hline T2 & $11.22 \mathrm{~b}$ & $10.48 \mathrm{~b}$ & $10.85 \mathrm{~b}$ & - & - & - \\
\hline T3 & $29.30 \mathrm{c}$ & $31.10 \mathrm{c}$ & $30.20 \mathrm{c}$ & $393 \mathrm{a}$ & $448 \mathrm{a}$ & $420 \mathrm{a}$ \\
\hline T4 & $18.20 \mathrm{~d}$ & $16.84 \mathrm{~d}$ & $17.52 \mathrm{~d}$ & $189 \mathrm{~b}$ & $189 \mathrm{~b}$ & $189 \mathrm{~b}$ \\
\hline T5 & $32.65 \mathrm{e}$ & $33.90 \mathrm{e}$ & $33.27 \mathrm{e}$ & $465 \mathrm{c}$ & $509 \mathrm{c}$ & $487 \mathrm{c}$ \\
\hline T6 & $11.80 \mathrm{~b}$ & $12.70 \mathrm{f}$ & $12.25 \mathrm{f}$ & $50 \mathrm{~d}$ & $98 \mathrm{~d}$ & $74 \mathrm{~d}$ \\
\hline Mean & 18.78 & 18.86 & 18.82 & 274 & 311 & 292 \\
\hline
\end{tabular}

II Means within the same column followed by the same letter are not significantly different at $\alpha=0.05$

Fig.1 Urea super granule, USG (left) and ordinary urea, OU (right)
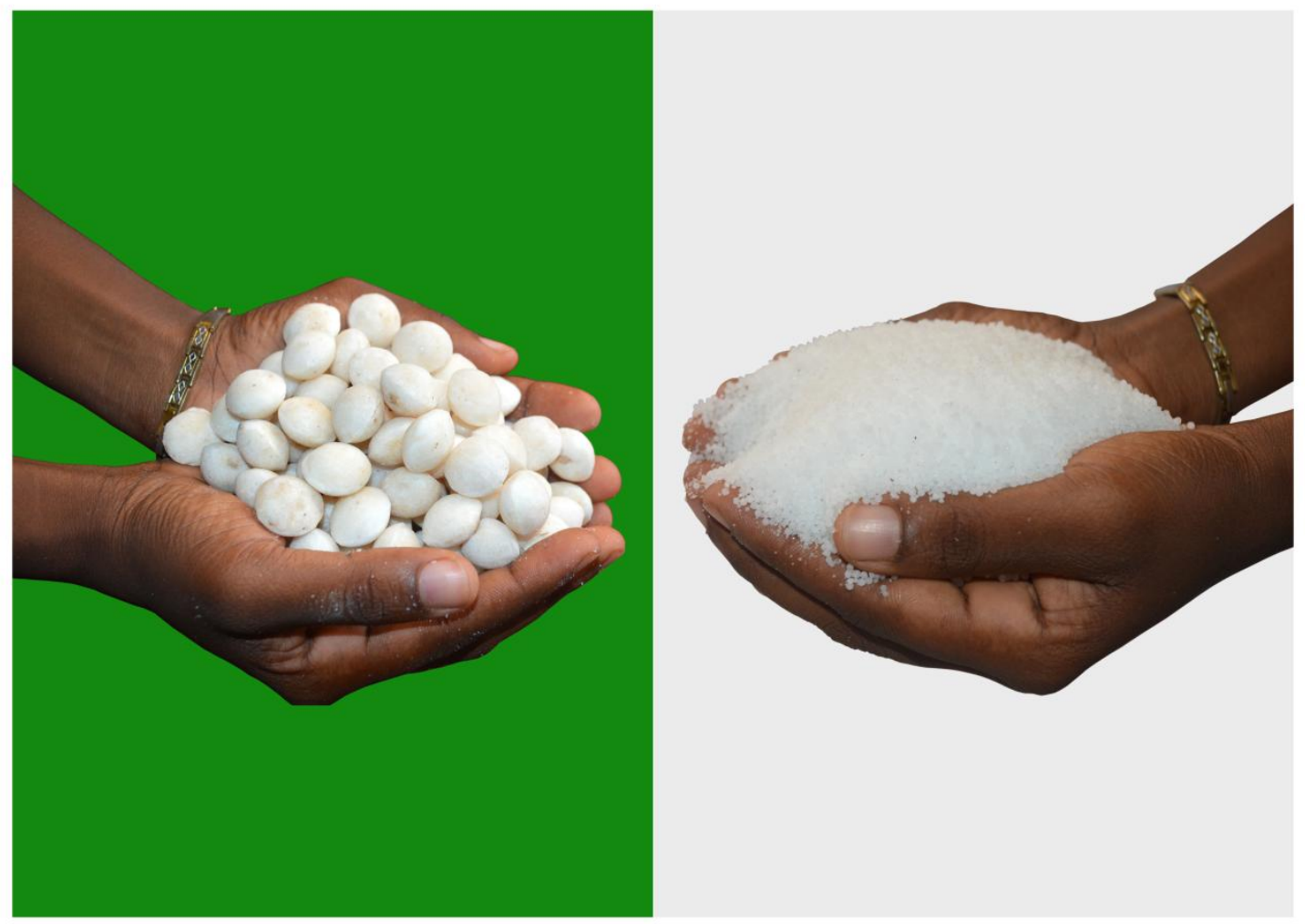
Fig.2 Small scale design (for up to $500 \mathrm{~m}^{2}$ ) with buckets of 200 liters releasing water to plants through a dripping system

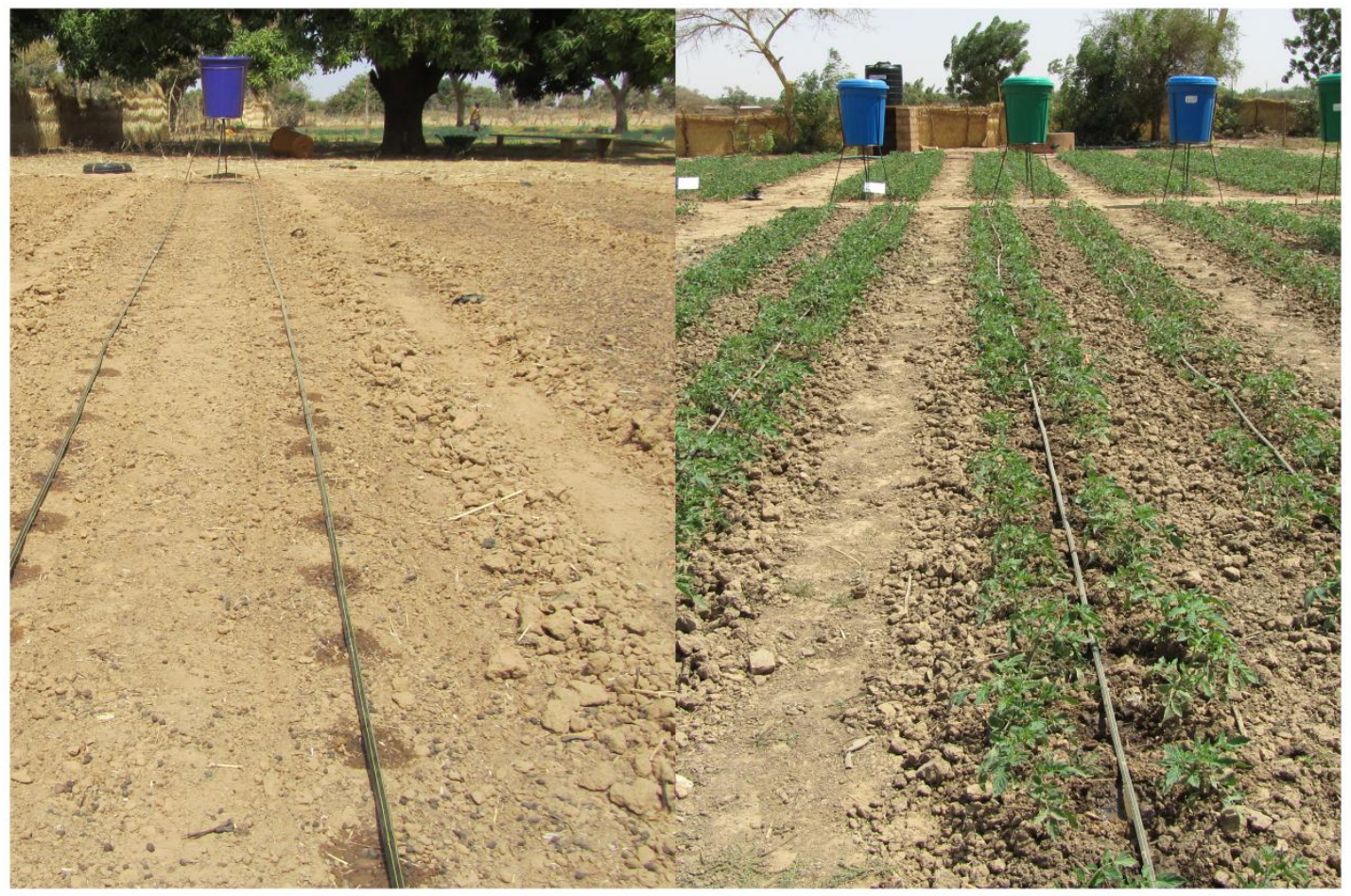

In the light of the results from the field experiment, off-season tomato production in the Savanna region of northern Togo should not be undertaken without mineral fertilizer application. Traditional hand watering practice may be used together with $\mathrm{N}$ fertilizer in the form of prilled urea. Hand watering is not recommended when the urea super granule form of $\mathrm{N}$ is applied because such a watering system-fertilizer combination led to drastically low yields and $\mathrm{N}$ agronomic efficiency index. The dripping bucket irrigation system proved capable of substantially improving tomato yield and $\mathrm{N}$ agronomic efficiency index under both prilled urea and urea super granule forms of $\mathrm{N}$, with a greater performance when urea super granule is used.

\section{Acknowledgement}

The authors acknowledge thankfully the International Fund for Agricultural
Development (IFAD) for financially supporting this work.

\section{References}

Abramson, A., Becker, N., Garb, Y. and Lazarovitch, N. 2011. Willingness to pay, borrow, and work for rural water service improvements in developing countries, Water Res. Res., 47: W11512, doi:10.1029/2010WR010147.

AVRDC (Asian Vegetable Research Development Center). 2006. Vegetables Matter. The World Vegetable Center, Shanhua, Taiwan.

Badr, M.A., Shaymaa, I.S. and Abou Hussein, S.D. 2012. Tomato Fruit Yield and Nitrogen Use Efficiency as Affected by Drip Irrigation Method and Rate of Nitrogen in a Hot Dry Climate. J. Appl. Sci. Res., 8(8): 4486-4495.

Boyhan, G., Granberry, D. and Kelley, T. 2001. Onion production guide, Bulletin 1198. College of Agricultural and 
Environmental Sciences, University of Georgia, p. 56.

de la Peña, R. and Hughes, J. 2007. Improving Vegetable Productivity in a Variable and Changing Climate. SAT eJournal., ejournal.icrisat.org., 4(1):1-22.

Detchinli, K.S. and Sogbedji, J.M. 2015. Maize Nitrogen Use Efficiency as Affected by Fertilizer Nitrogen Form and Rate of Application in the Guinea Savanna Agro Ecological Zone of West Africa. Int. Curr. Res. Aca. Rev., 3(10): 222-233.

Djidonou, D., Zhao, X., Simonne, E.H. and Koch, K.E. 2013. Yield, water-, and nitrogen-use efficiency in field-grown, grafted tomatoes. Hortsci., 48(4): 485492.

DRPDATS (Direction Régionale de la Planification, du Développement et de l'Aménagement du Territoire des Savanes). 2013. Monographie de la Région des Savanes. Dapaong, Togo.

FAO (Food and Agriculture Organization of the United Nations). 2006. Agricultural data FAOSTAT. Rome, Italy.

Fathi, K. 1996. New outlook on nutrient use efficiency (with emphasis on element nitrogen). Integrated research Ramin Agricultural Higher Education. Shahid Chamran University, Iranian Crop Science Congress reform Articles, pp. 283-266.

Friedlander, L., Tal, A. and Lazarovitch, N. 2013. Technical considerations affecting adoption of drip irrigation in sub-Saharan Africa, Agri. Water Manage., 126:125132.

IFDC (International Fertilizer Development Center). 2014. Mainstreaming pro-poor fertilizer access and innovative practices in West Africa. IFAD Technical Assistance Grant No. 1174 report. Muscle Shoals, Alabama, U.S.A.

Kaniszewski, S. and Dysko, J. 1988. Effect of different irrigation systems on yield of tomatoes grown under plastic greenhouses. Acta Hortic., 228: 105-108.

Ngigi, S., Savenije, H., Thome, J.N., Rockstrom, J. and Penning de Vries, F. 2005. Agro-hydrological evaluation of on-farm rainwater storage systems for supplemental irrigation in Laikipia district, Kenya. Agri. Water Manage., 73: 21-41.

Polak, P., Adhikar, D., Nanes, B., Salter, D. and Suryawanshi, S. 2003. Transforming rural water access into profitable business opportunities, In: Proceedings of the International symposium on Water, Poverty and Productive Uses of Water at the Household Level, Muldersdrift, South Africa, 21-23 January, 2003.

Tarfa, B.D. and Ahmed, B. 2011. Study on economics of UDP technology on rice production in Nigeria. IFDC (International Fertilizer Development Center) Technical Report. Lomé, Togo.

von Westarpa, S., Chieng, S. and Schreiera, H. 2004. A comparison between low-cost drip irrigation, conventional drip irrigation, and hand watering in Nepal. Agri. Water Manage., 64: 143-160.

Woltering, L., Ibrahim, A., Posternak, D. and Ndjeunga, J. 2011. The economics of low pressure drip irrigation and of hand watering for vegetable production in the Sahel, Agri. Water Manage., 99: 67-73.

\section{How to cite this article:}

Jean Mianikpo Sogbedji, Kodjovi Sotomè Detchinli, Kossivi Koukoude, Robert Baname Gbengbernaba and Jean Tadanlenga Yatombo. 2017. Water and Fertilizer Use Management for Improving Smallholder Farmers' Tomato Production in the Dry Savanna Agro Ecology of West Africa. Int.J.Curr.Microbiol.App.Sci. 6(8): 718-724. doi: https://doi.org/10.20546/ijcmas.2017.608.091 